Design-related questions in the construction phase : The effect of using the Last Planner System in design management

\title{
Mäki, Tarja
}

2020-02

Mäki , T \& Kerosuo , H 2020 , ' Design-related questions in the construction phase : The effect of using the Last Planner System in design management ' , Canadian Journal of Civil Engineering , vol. 47 , no. 2 , pp. 132-139 . https://doi.org/10.1139/cjce-2018-0382

http://hdl.handle.net/10138/335185

https://doi.org/10.1139/cjce-2018-0382

unspecified

acceptedVersion

Downloaded from Helda, University of Helsinki institutional repository.

This is an electronic reprint of the original article.

This reprint may differ from the original in pagination and typographic detail.

Please cite the original version. 


\section{Title Page}

Design-related questions in the construction phase: The effect of using the Last Planner System in design management

\section{Authors}

Tarja Mäki

Hannele Kerosuo

Affiliation and address at the time of the study ${ }^{1}$ (both authors)

Affiliation: Centre for Research on Activity, Development and Learning University of Helsinki

Address: Siltavuorenpenger $1 \mathrm{~A} / \mathrm{PO}$ Box 9

00014 University of Helsinki, Finland

Contact information of the corresponding author

Name: $\quad$ Tarja Mäki

Email_tarja.maki@mittaviiva.fi

${ }^{1}$ Faculty of Educational Sciences, Department of Education/CRADLE

Siltavuorenpenger 1-5, 10 / PO Box 9

00014 University of Helsinki 


\title{
Design-related questions in the construction phase: The effect of using the Last Planner System in design management
}

\begin{abstract}
This study explores designers, engineers and managers sharing their knowledge and resolving design-related issues during construction site meetings. It provides new insights into the collaboration and the expertise of the different partners. In addition, the study provides new knowledge of using LPS in the design phase and its influence on the site meeting discussions in the construction phase. The research data comprise video recordings of 17 site meetings in two BIM-based renovation projects. Based on this data, the construction managers were the most active in addressing issues, but all partners were actively involved in the discussion and shared their expertise to address the open questions. The use of the Last Planner System in the design phase seemed to decrease the number of design-related open questions in the construction phase. The findings emphasize the need to develop more collaborative design management methods and practices for sharing each expertise.
\end{abstract}

\section{Keywords}

construction management, Last Planner System, building information modelling, site meeting, discussion

\section{Introduction}

Traditionally, construction work is based on a distributed division of labour in which each design discipline produces their respective designs. Builders from different fields are in charge of the construction work based on those designs. Carrying out construction projects, however, is a collaborative activity that calls for multi-disciplinary expertise, knowledge sharing and collaboration beyond the boundaries of different fields. The collaboration is customarily carried out and coordinated in different project meetings during the design and construction phases. In these meetings, the progress of the design and construction work is monitored, emerging issues discussed, and design solutions developed. (Lyon 2013)

In recent years, construction project collaboration has been the subject of several studies. Building information modelling (BIM) has been seen as a possible catalyst for making design and construction activities more collaborative and for increasing performance, accuracy and quality in the design and construction process (Eastman et al. 2011; Hardin 2009; Li et al. 2009). At the level of practices, this development has created the need for new forms of collaboration towards co-working and contracting, regulating the interaction between stakeholders (Fischer et al. 2017; Miettinen \& Paavola 2014; Lahdenperä 2012). What is called for at the project level is active collaboration between the different partners in design and construction. 
Collaboration between construction site management and designers during project meetings has recently been studied, for example by tracing patterns of interaction and communication networks, and by making a distinction between task-based and socioemotional interaction (Foley \& MacMillan 2005; Boudeau 2013; Gorse \& Emmitt 2007, 2009). However, the topics of project meeting discussions have not been the focus of previous studies. In addition to collaboration between project partners, design management practices have also been seen as crucial in terms of the quality of design processes, or design error management (Al Hattab \& Hamzeh 2015). In construction projects, design management has sometimes appeared to be chaotic and improvised (Koskela et al. 1997). The Last Planner System (LPS) has duly been suggested as a method for managing this project 'chaos' (Bertelsen \& Koskela 2005).

This study focuses on the site meeting discussions held during two renovation projects in Finland. The site meetings were a continuation of the design meetings and chaired by a developer's project manager once a month in the site office. Drawing on practicebased approaches (Gherardi 2012; Nicolini 2012; Engeström 2015/1987), the discussions are examined from the perspective of being interrelated with the project work at hand. To this end, the study has two goals. Firstly, it aims to provide new insights into the collaboration between designers and construction managers by investigating the content of discussions and the expertise of the different partners in making decisions or in producing new design solutions. Secondly, it aims to examine whether using LPS in the design phase will have an influence on the site meeting discussions in the construction phase.

The study contributes to the organization and practices of the collaboration between construction and design management by highlighting the need to enhance the quality of discussion and interaction in the interphase of design and construction management. The quality of this engagement could in turn enhance knowledge and lead to improved solutions when addressing design-related open questions in the construction phase. The first two sections of the article discuss the previous research and introduce the theoretical framework and methodology for studying the design and construction interface. The research site, data and methods adopted are then introduced, and the findings presented. Lastly, the findings are discussed in the context of the research literature, followed by the conclusions of the study.

\section{Previous studies on design and construction interfaces}

The importance of collaboration between designers and contractors in construction projects has been emphasized in several studies. For example, Gerth and colleagues (Gerth et al. 2013) have studied the way in which production experiences have been utilized in design work to improve constructability. They argue that the inability to utilize acquired experiences is a potential source of low quality and high construction costs in projects (Gerth et al. 2013). The early involvement of contractors in the design process results in fewer constructability problems, lower project costs and faster completion rates during the construction phase (Trigunarsyah 2007). 
Sacks et al. (2015) studied the dialogues between designers and builders carried out using virtual reality tools to improve the safety on sites. The results showed that consultation and dialogue with an experienced construction professional were highly beneficial for on-site safety (Sacks et al. 2015). Al Hattab and Hamzeh (2015), for their part, argued that novel design error management and the use of BIM and lean practices enable design teams to modify their collaboration, identify design errors earlier and reduce their reoccurrence.

In recent years, several studies have been published on communication behaviour, interaction and coordination in project meetings (Foley et al. 2005; Boudeau 2013; Gorse et al. 2007, 2009). According to Gorse and colleagues (2007, 2009), meeting discussions are highly task-based, and mainly take place between project managers, contractors and architects.

Dossick and Neff (2011) have studied inter-organizational collaboration among design and construction professionals in building projects. They found BIM to be an efficient tool for exchanging explicit knowledge. However, 'messy talk' and informal, active and flexible conversations are needed to exchange tacit knowledge. They also argue that deeply embedded disciplinary thinking is not easy to overcome using digital representations of knowledge. (Dossick \& Neff 2011)

Poirier et al. (2016) have explored the notion of collaborative expertise in the construction field and the implications of innovative project delivery approaches for this expertise. They cite Pryke (2004, p. 790), pointing out that: "In the AEC sector, collaboration is imperative: it is not a matter of if organizations should collaborate but how should they collaborate. Ultimately, collaboration aims to support the building project." They also note that emerging project delivery approaches, such as BIM, IPD or Lean Design and Construction, underline the importance of collaboration between the project partners when the aim is to improve the performance of construction projects (Pryke 2004).

All of the above-mentioned studies underline the need to study the forms of collaboration in construction projects. However, they do not examine the content of the issues discussed in the project meetings or how the participants take part in the discussions. Gorse et al. (2007) argue that it is too detailed or too project-specific to analyse who is saying what to whom. Alarcón and Mardones (1998) have, however, studied design defects and their effects on a construction process. According to them, the problems associated with the designs mainly represented 1) poor design quality, 2) a lack of design standards, and 3) poor constructability of designs. They argue that the designers' poor construction knowledge was a primary reason for the problems. Their recommendation for solving these problems is to incorporate construction personnel into the design phase. (Alarcón et al. 1998) In addition, Koskela et al. (1997) refers to a study of construction defects by Josephson et al. (1996) in which the design-caused defects were found to be the biggest defect category when measured by cost. It emerged that those design-caused defects originating from a lack of coordination constituted the largest category. The main direct cause of defects in design was identified as lack of knowledge about the specific task (Josephson 1998). The findings of the above- 
mentioned studies emphasize the need to explore the notion of collaboration at a higher level, but also the need to study the practices and the content of collaboration in the interphase of design and construction management activities at the project level.

LPS is a method that has been more typically utilized in construction production to increase the reliability of production planning, improve production performance and create a predictable production workflow (Ballard 2000; Hamzeh et al. 2009). Even though its use has achieved positive results in production, it has been implemented in design processes much less often. Studies have raised the question of whether LPS could also serve design processes that involve iterations and circular chains of interaction between different parties. (Hamzeh et al. 2009) In current design management studies, the benefits of LPS have been examined from the point of view of the design phase activities: how it changes the collaboration between the designers and other partners, or how it enables the design team to adhere to the design schedule (Hamzeh et al. 2009; Kerosuo et al. 2012). These analyses do not cover the potential benefits during production activities, however, which is one of the goals of this study.

\section{Theoretical framework and methodology for studying construction site meetings}

In practice-based studies, meetings are not only seen as settings in which discussions are regarded as simply talk for talk's sake, but also as opportunities for getting things done (Gherardi 2012; Nicolini 2012; Engeström 1999). Talk and action are interrelated in the construction and maintenance of social practices (Gluch \& Räisänen 2009; Gluch et al. 2013). Some scholars even say that practices and negotiated interactions may be considered much more important than industry-wide models of partnering in the construction industry (Bresnen 2009). Collaboration and negotiations cannot be separated from practices in meetings, and discussions are not situations of 'pure talk' or off-line conversations in meetings (Gherardi 2012). Each participant aims to advance their own purposes or goals for their actions through discussions during construction site meetings (Mäki 2015).

Cultural-historical activity theory examines talk and action in the framework of objectoriented activity systems (Engeström 2015/1987). The term practice is either used in its general sense or in its specific meaning to describe a certain way of doing things in an activity. The subjects' actions are mediated by tools and signs when they work on objects of activity, as well as by the rules, division of labour and community in an activity system. An object of activity is an enduring, constantly reproduced purpose of a collective activity system. It motivates and gives direction to the goals and (inter)actions of different stakeholders. (Engeström 1995)

In the current world of work, activity is carried out in two or more activity systems in which each activity system focuses on partially shared objects besides the object of the activity itself (Engeström 2001). Figure 1 shows a general model of two activity systems working on a shared object. 


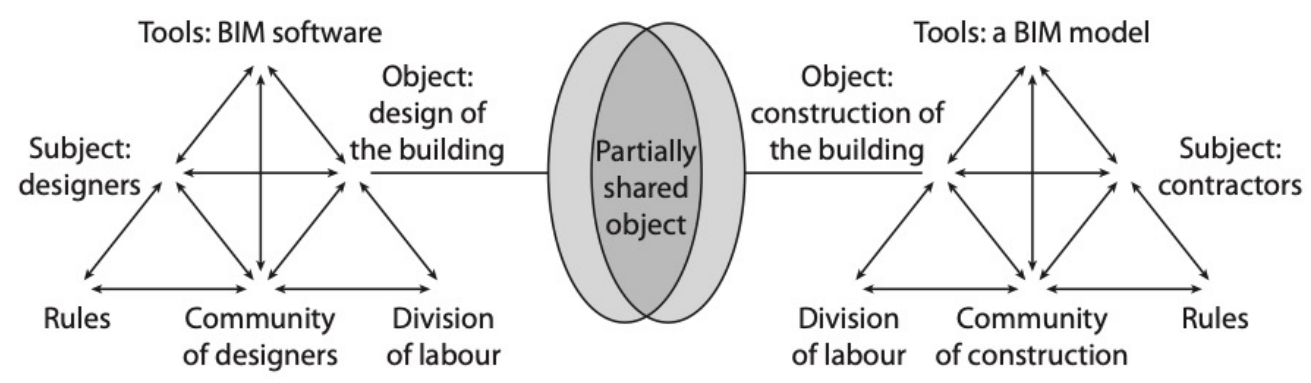

Figure 1. Partially shared object of two activity systems of design and construction (adapted from Engeström 2001, 136).

Activity systems are not stable constructions; in real life they are in constant movement due to their connections to the changing environments (Engeström 2015/1987). For instance, the implementation of BIM has been affected by creating tensions between old and new practices in organizations and practices of construction activity. The changes in the context create tensions and contradictions between the structural elements of an activity system that require new discussion and negotiation among practitioners. (Kerosuo et al. 2015)

Activity systems can be interrelated in different ways in fluid organizational fields characteristic of the current network-type working mode. They can also represent a process of work activity in which one activity can relate to other activity systems through tools, and rules of division of labour. Two or more activity systems can also be interrelated across different levels of an activity such as managerial and hands-on activity. (Engeström 2008)

The theoretical framework of this study consists of two interrelated activity systems of design and construction management. The design activity system is working on the object of building designs produced in a digital form to be used as tools in the construction management activity system (see Figure 2).

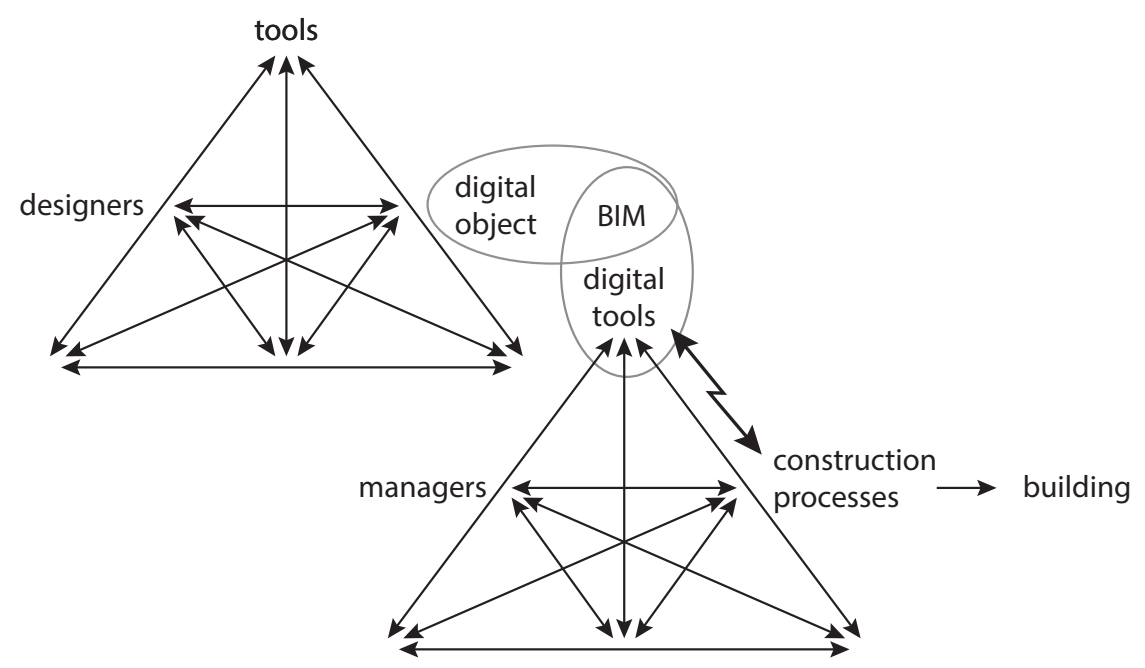

Intertwined activity systems of design and construction management.

Figure 2. Intertwined activity systems of design and construction management (modified from Engeström \& Sannino 2010, 6). 
In the ethnographic methodology of this study, the discussions are observed in situ as interactions between the design activity system and the construction management activity system. This methodological choice follows the insights of traditions in the ethnographies of design engineering: interviews and surveys are not sufficient to uncover problems or challenges or the actual collaboration between partners. (Buchiarelli 1988; Henderson 1999; Miettinen et al. 2012) Interactions are connected through the design objects to the design activity system and provided as design tools for the construction management activity system in concrete construction projects. The design activity system is formed from several separated but interconnected design solutions. Through the activity theoretical lens, these can be examined as local objects. Correspondingly, the object of a contractor's activity is to construct the building, while the overall object can be divided into local objects of building parts or construction tasks. (Mäki \& Kerosuo 2015; Mäki 2015) These local objects are discussed in site meetings from the different perspectives of each project partner.

\section{$4 \quad$ Field of study, data and research methods}

The data for this study form part of a larger corpus of ethnographic data collected by interviewing and shadowing construction site managers on several construction sites (Mäki et al. 2015), and by observing different project meetings in two renovation projects in Central Finland. The renovation projects were part of a life-cycle project that included four schools and one day-care centre. The design and construction companies were the same for all projects. The projects under study were equal in their complexity, size, timeframe and the involvement of contractors. All of the designers provided BIM models, and the models were in active use in the construction phases. Site meetings were selected as cases for the study because they provided a regular event for examining the collaboration between designers and managers. (Mäki 2015)

As the researchers interviewed the project partners at the beginning of the study, the findings revealed challenges in the quality of the design work, the design collaboration, and in adherence to the design schedule Due to the challenges, the project manager decided to implement LPS in design management during the second project. The design team held an LPS meeting every second week during the design phase of the project. The implementation of LPS resulted in several changes to the design meetings. Among other things, the temporal orientation of the discussions became proactive, and the interdependency between the different design disciplines became more visible. (Kerosuo et al. 2012)

The ethnographic method of data collection was participant observation, according to which an ethnographer becomes immersed in the field of study by being present (Fetterman 2010). Observing the project participants in their natural work situations was necessary in order to discover the actual collaboration and discussions between them. As a participant observer, the researcher attended the meetings and the site tours, wrote field notes, took photographs, and audio- and video-recorded the discussions. The 
video-recorded data were transcribed verbatim and divided into speech turns. Every speaker's utterance on the recordings was counted as a speech turn.

The data comprised approximately 30 hours of video-recorded observation data, in which 412 design-related issues were discussed. The data are presented in Tables 1 and 2. The duration, number of participants, number of discussions and analysed speech turns are presented to give the reader a more comprehensive understanding of the meetings, not for analytical reasons.

Table 1. Site meetings between 2011 and 2012 (Project 1)

\begin{tabular}{|c|c|c|c|c|}
\hline of site meeting & tion & $\begin{array}{l}\text { Jer of } \\
\text { :ipants }\end{array}$ & $\begin{array}{l}\text { Jer of } \\
\text { ssion } \\
\text { des }\end{array}$ & Ised speech \\
\hline spt 2011 & $\operatorname{nin}$ & & & \\
\hline st 2011 & $\operatorname{nin}$ & & & \\
\hline JV 2011 & $\operatorname{nin}$ & & & \\
\hline əс 2011 & in & & & \\
\hline In 2012 & in & & & \\
\hline sb 2012 & in & & & \\
\hline ar 2012 & in & & & \\
\hline Jr 2012 & $\operatorname{nin}$ & & & \\
\hline \multicolumn{5}{|l|}{ әcorded } \\
\hline & $17 \min$ & & & \\
\hline
\end{tabular}

Table 2. Site meetings between 2012 and 2013 (Project 2)

\begin{tabular}{|c|c|c|c|c|}
\hline of site meeting & tion & $\begin{array}{l}\text { Jer of } \\
\text { :ipants }\end{array}$ & $\begin{array}{l}\text { Jer of } \\
\text { ssions }\end{array}$ & Ised speech \\
\hline$\overline{\lg 2012}$ & nin & & & \\
\hline əpt 2012 & nin & & & \\
\hline zt 2012 & $\operatorname{nin}$ & & & \\
\hline \multicolumn{5}{|l|}{ ecorded } \\
\hline әс 2012 & in & & & \\
\hline In 2013 & $\operatorname{nin}$ & & & \\
\hline b 2013 & in & & & \\
\hline ar 2013 & $\operatorname{nin}$ & & & \\
\hline jr 2013 & $\operatorname{nin}$ & & & \\
\hline \multirow[t]{2}{*}{ ay 2013} & in & & & \\
\hline & $88 \mathrm{mir}$ & & & \\
\hline
\end{tabular}


The theoretical concepts of an object of activity and tools are used as analytical concepts in the study. The analysis of the data was carried out in an inductive, data-driven way typical of qualitative studies. The data-driven approach elucidates the culture under study, namely the practices of social interaction in construction site meetings in this case. (Fetterman 2010)

The unit of analysis is a discussion episode, which typically starts with a meeting participant raising an issue that needs to be discussed during the meeting. The discussion episode usually continues with a general discussion, suggesting new solutions, asking and answering questions, and presenting different points of view. The discussion episode ends when a decision is made about the issue under discussion, or when a new issue is raised.

The definition of the unit of analysis in ethnographic analysis is not related to quantification in the sense of quantitative studies, but to understanding the main features of the culture under study, namely social interaction in construction site meetings, in order to provide analytical robustness (Boellstorff et al 2012). Therefore, the validity of the findings is not comparable to the results of quantitative studies. The purpose of the study and the methods adopted are different, and the sample is usually small.

The analysis began by identifying all of the design-related discussion episodes in the data. These 412 episodes were collected on an Excel spreadsheet. Each discussion episode was analysed and categorized to identify:

- the topic of the discussion episode

- who opened the discussion episode

- the reason for raising the topic

- participation in the discussion

- number of speech turns in the episode

- decision made (if any)

- on whose arguments the decision was based.

The discussion episodes involved several speech turns and perspectives. Sometimes a solution was suggested and accepted based on the expertise of one party, with no opposing suggestions. In other cases, different parties supplemented a new solution with their expertise, in which cases the discussion could be compared to piecing a mosaic together. Occasionally, the discussion revealed that the views of the participants were in opposition. In the analyses, the whole discussion episode was studied to identify the critical comments or turning points that led to the final decision. All of these parties were interpreted as contributing expertise to the decision.

\section{Findings}

The site meetings were a direct continuation of the design meetings. The meetings were held once a month and chaired by the project manager. The site managers attended the site meetings along with the designers, supervisors, the maintenance manager and other partners. At the beginning of each meeting, they took a site tour and viewed the status of the construction work and design-related issues to be addressed in the meeting. 
The agenda of the construction site meetings was 1) the opening of the meeting; 2) the meeting agenda; 3 ) the previous meeting's minutes; 4) official matters; 5) construction workforce status; 6) the project schedule; 7) procurements; 8) work safety and environmental matters; 9) financial matters; 10) the chief contractor's matters; 11) the HVAC contractor's matters; 12) the status of the design work, the designers' matters; 13) the developer's matters; 14) risks in the project; 15) other matters; and 16) the next meeting (Mäki 2015).

The site meetings were long and the participants were actively engaged in discussions. The chief site managers presented a list of open design-related issues to facilitate the discussion.

\subsection{Which design-related issues were addressed in the site meetings and why were they addressed?}

The number of discussions varied from one meeting to another in both projects, and were most frequent at the beginning of projects. When the construction phase of Project 1 started, some of the initial data required for the design work was unavailable, and this work duly fell behind schedule. Project 2, which had utilized LPS in design management, started more easily and had less discussion at the beginning, but the discussion rate rose again when delays in the demolition work became apparent.

The design of the grounds, building service technology, wall structures, furnishings and equipment, and windows and doors were the most frequently addressed topics. Common modelling procedures were also a recurring topic. Table 3 presents the most frequently discussed topics and the number of discussions on each topic in both projects.

Table 3. Design-related topics discussed in the site meetings.

\begin{tabular}{lll|ll}
\hline Discussion topic & $\begin{array}{l}\text { Total number of } \\
\text { discussions }\end{array}$ & $\%$ & Project 1 & Project 2 \\
\hline Grounds & 47 & 11 & 23 & 24 \\
\hline Building service technology & 35 & 8 & 21 & 14 \\
\hline Wall structures, surface materials & 34 & 8 & 19 & 15 \\
\hline Furnishings, equipment & 32 & 8 & 19 & 13 \\
\hline Windows, doors & 27 & 7 & 20 & 7 \\
\hline The gym & 25 & 6 & 8 & 17 \\
\hline Procedure and design & 21 & 5 & 11 & 10 \\
\hline Roof and eaves structures & 19 & 5 & 14 & 5 \\
\hline Electrical installation & 18 & 4 & 9 & 9 \\
\hline Ducts & 17 & 4 & 9 & 8 \\
\hline Floor structures and materials & 17 & 4 & 9 & 8 \\
\hline Ceiling structures and materials & 15 & 4 & 8 & 7 \\
\hline Other (19 different topics, $<15)$ & 105 & 25 & & 187 (45\% \\
\hline Total & 412 & & $225(55 \%)$ & \\
\hline
\end{tabular}

The reasons for raising issues in the meetings are presented in Table 4. For the designers, a typical reason was the need to clarify the initial information for the design. Other reasons were mainly addressed by the contractors: for example, a design 
document did not exist, or lacked the required design information. Still, the most typical reason was the need for changes to an existing design. The contractors made suggestions for developing the design solutions. Work procedures were also discussed in that the designers were asked to update the existing designs, or were informed about a deviation in implementing a design, and its effects on the progress of the project.

Table 4. Reasons presented by the participants for initiating a discussion in the site meetings.

\begin{tabular}{|c|c|c|c|}
\hline Reason for initiating a discussion & $\begin{array}{l}\text { Total number of } \\
\text { reasons }\end{array}$ & Project 1 & Project 2 \\
\hline Initial data need to be clarified. & 18 & 18 & 0 \\
\hline A design document does not exist. & 57 & 35 & 22 \\
\hline $\begin{array}{l}\text { A design document exists, but lacks the } \\
\text { necessary design solution. }\end{array}$ & 40 & 31 & 9 \\
\hline $\begin{array}{l}\text { An existing design solution requires } \\
\text { modification or specification. }\end{array}$ & 180 & 75 & 105 \\
\hline $\begin{array}{l}\text { A new suggestion for a design solution } \\
\text { raised by a contractor. }\end{array}$ & 18 & 11 & 7 \\
\hline $\begin{array}{l}\text { A contractor indicates an execution } \\
\text { divergent from a design document. }\end{array}$ & 6 & 4 & 2 \\
\hline A design document needs to be updated. & 15 & 12 & 3 \\
\hline Common procedures need to be discussed. & 17 & 5 & 12 \\
\hline Other & 38 & 16 & 22 \\
\hline
\end{tabular}

\subsection{How did different stakeholders participate in the discussions, and on whose expertise were the decisions based?}

Figure 3 illustrates how the different stakeholder groups took part in the design-related discussions. The PM group includes only the project manager, the head of the renovation project. The designers' group includes all of the designers, and the contractors' group all of the contractors' managers. The group labelled 'Other' includes supervisors, and life-cycle and maintenance managers. As shown, the contractors were the most active group in raising design-related issues, bringing up close to $70 \%$ of all issues in both projects. 


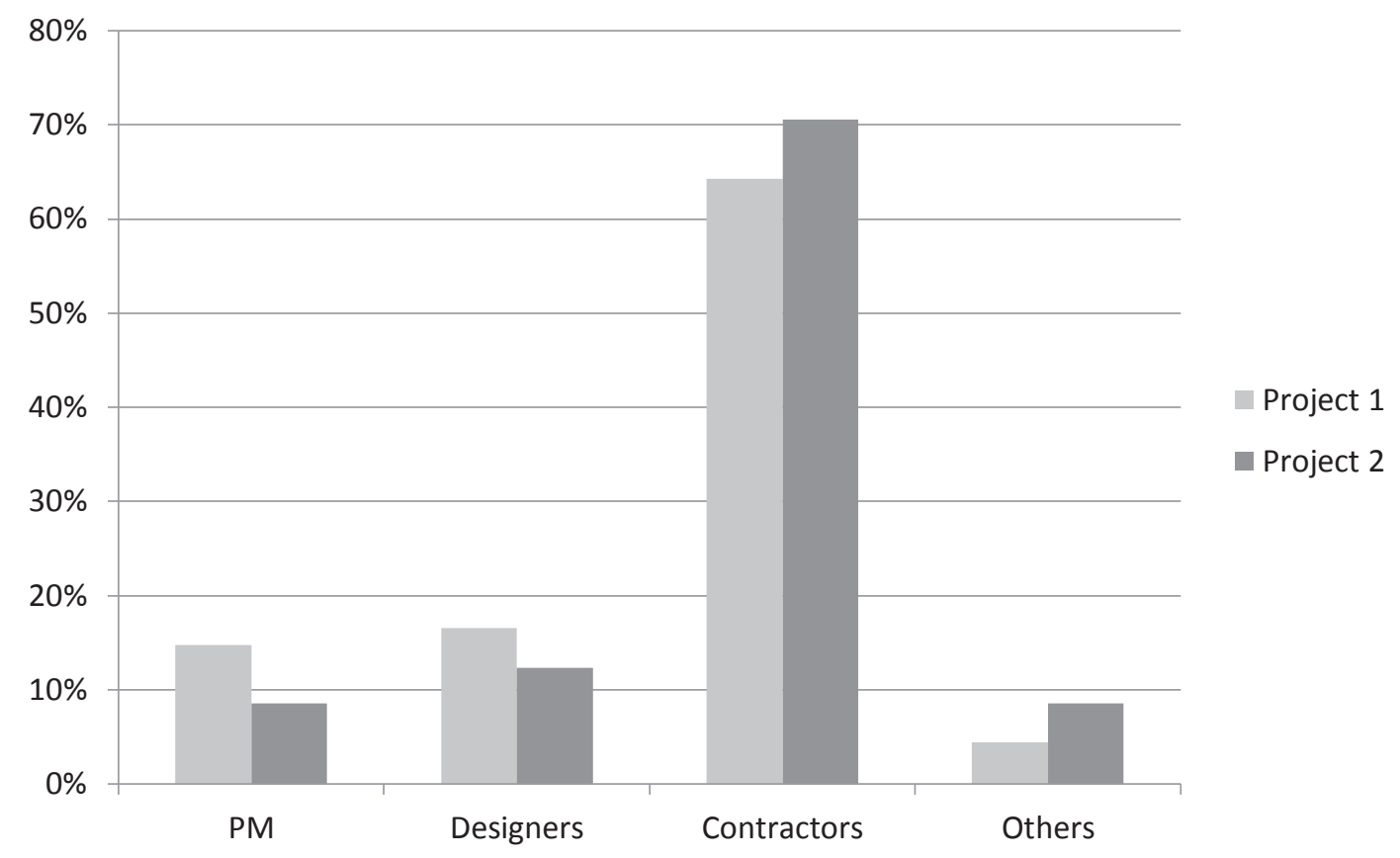

Figure 3. Design-related issues and open questions raised in the site meetings.

Although the contractors were active in initiating discussions, all of the parties were actively involved in the discussions in both projects (see Figure 4). The discussions were mainly held between the contractors, the designers and the project manager. When a discussion covered life-cycle or quality issues, the life-cycle and maintenance managers, and the supervisors took an active part.

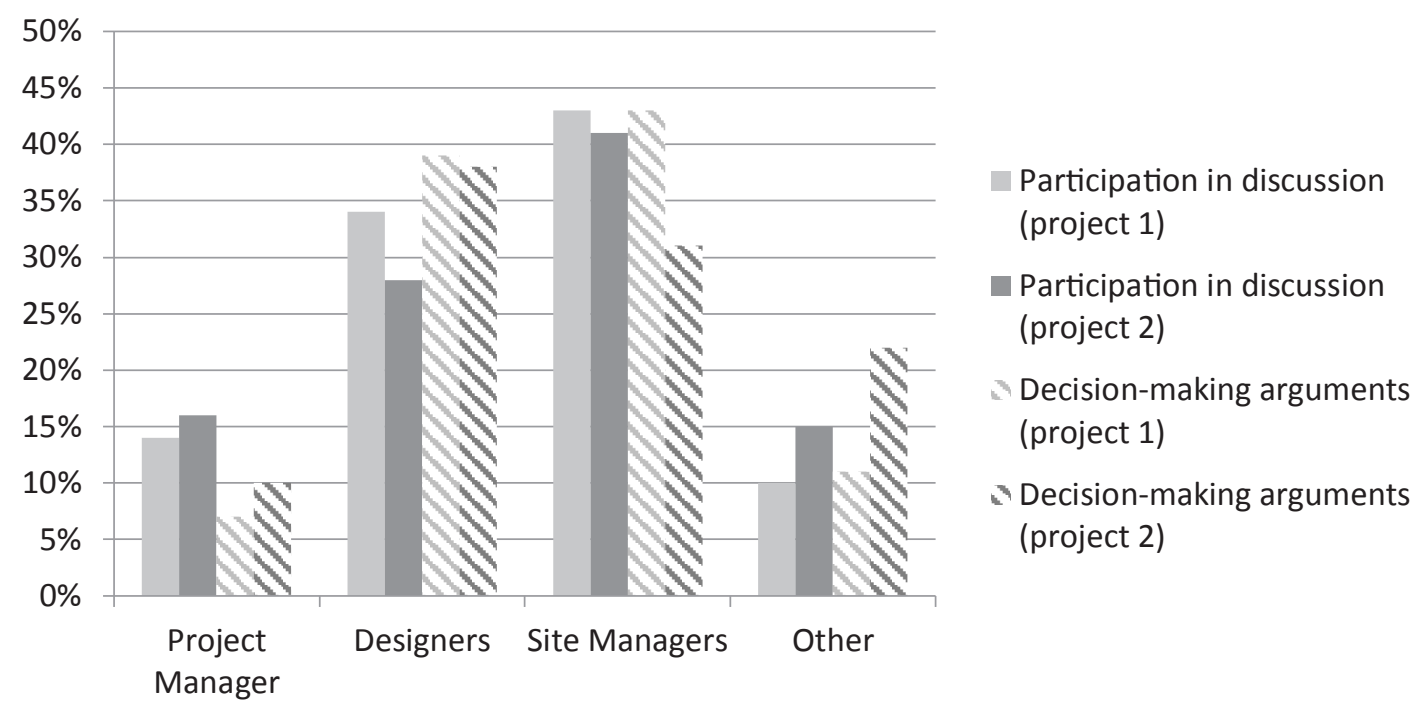

Figure 4. Participation in the design-related discussions in the site meetings and identification of whose expertise created the design solutions.

The following example shows how the designers, supervisor, contractors and maintenance manager discussed the same topic, but how they focused on very different aims when solving the open question at hand. 
Table 5. A discussion episode

\begin{tabular}{|c|c|}
\hline Dialogue & Aim of speech \\
\hline MM: We should talk about the toilets for disabled people... & Modification of design \\
\hline \multicolumn{2}{|l|}{ PM: Have you already solved the problem? } \\
\hline $\begin{array}{l}\text { MM: Well, there is a rule, the toilet seat should be } 300 \mathrm{~mm} \text { from the } \\
\text { wall. }\end{array}$ & Modification of design \\
\hline \multicolumn{2}{|l|}{ PM: Is there? } \\
\hline $\begin{array}{l}\text { MC: Shall we move the toilet seat, or shall we keep it where it is now } \\
\text { - please, just make the decision so we can start the work. }\end{array}$ & $\begin{array}{l}\text { To know how to proceed with } \\
\text { the construction work }\end{array}$ \\
\hline $\begin{array}{l}\text { MM: In practice, there has to be a gap of } 500 \mathrm{~mm} \text {, if you have to stand } \\
\text { between the toilet seat and the wall... }\end{array}$ & Better usability \\
\hline $\begin{array}{l}\text { ARC: There is a rule of } 300 \mathrm{~mm} \text {, but it is a requirement for a } \\
\text { wheelchair, not for a person. }\end{array}$ & To maintain the current solution \\
\hline $\begin{array}{l}\text { MM: Still, should we move the toilet seat some } 200 \mathrm{~mm} \text { from the wall? } \\
\text { We have plenty of time to do it. }\end{array}$ & Modification of design \\
\hline MC: Does it concern only one toilet, in the basement...? & $\begin{array}{l}\text { To find out the amount of extra } \\
\text { work }\end{array}$ \\
\hline \multicolumn{2}{|l|}{ MM: Only this one. } \\
\hline PM: MC, it is not such a big deal. & Modification of design \\
\hline $\begin{array}{l}\text { MM: Let's install it } 500 \mathrm{~mm} \text { from the wall. And don't put the mirror on } \\
\text { the wall, behind the seat as designed. No one wants to knock it down } \\
\text { (when helping somebody in a wheelchair). }\end{array}$ & Better usability \\
\hline $\begin{array}{l}\text { HC: How about the water pipeline? Does it go in the floor and need } \\
\text { to be covered? }\end{array}$ & $\begin{array}{l}\text { To know how to proceed with } \\
\text { the work }\end{array}$ \\
\hline MM: Just like in the previous project. In the floor structures. & $\begin{array}{l}\text { A suggestion to execute the } \\
\text { work }\end{array}$ \\
\hline SV: It can be done like that. & To support the suggestion \\
\hline HC: Of course, we can do it that way but... & Need for a second opinion \\
\hline $\begin{array}{l}\text { MC: There is no need to make a track. As the drain is in the middle } \\
\text { of the room, we only need to... }\end{array}$ & $\begin{array}{l}\text { Modification of the previous } \\
\text { suggestion }\end{array}$ \\
\hline HC: We'd better not submerge the pipelines in the floor. & $\begin{array}{l}\text { To support the original } \\
\text { suggestion }\end{array}$ \\
\hline PM: If it is only that one... & $\begin{array}{l}\text { Back to the original discussion: } \\
\text { support for the modification of } \\
\text { design }\end{array}$ \\
\hline $\begin{array}{l}\text { MM: I think it was a good solution the way we did it in [the previous] } \\
\text { project. If it does not hinder the use of... }\end{array}$ & $\begin{array}{l}\text { A solution used in a previous } \\
\text { project }\end{array}$ \\
\hline $\begin{array}{l}\text { ARC: But it is } 500 \mathrm{~mm} \text { from the wall. It would be better in the middle } \\
\text { of the room, because it is so close to the door... }\end{array}$ & $\begin{array}{l}\text { To change the location of the } \\
\text { seat }\end{array}$ \\
\hline $\begin{array}{l}\text { MM: Hey, MC came up with an idea. How about if we don't move the } \\
\text { toilet seat from the wall but just turn it a little bit. Then you get behind } \\
\text { the seat but there is no need to make a track in the floor, and it won't } \\
\text { be in front of the door. }\end{array}$ & $\begin{array}{l}\text { A compromise between the new } \\
\text { and the suggested solutions }\end{array}$ \\
\hline \multicolumn{2}{|l|}{ (The discussion continues.) } \\
\hline $\begin{array}{l}\mathrm{PM}=\text { project manager, } \mathrm{MC}=\text { main contractor, } \mathrm{MM}=\text { maintenance } \\
\text { manager, } \mathrm{HC}=\text { heating contractor, } \mathrm{ARC}=\text { architect, } \mathrm{SV}=\text { supervisor }\end{array}$ & \\
\hline
\end{tabular}

The maintenance manager started the discussion by stating the requirement for space around a toilet seat for better usability. The architect defended the original design solution to avoid additional design work. The main contractor emphasized the need for 
a decision to be made as soon as possible to ensure their workflow. The project manager needed to know the extent of the change to estimate the cost effect for the whole project. At the same time, the heating contractor wanted to know how the change would affect his work. The discussion episode continued until the contractors jointly proposed a compromise to resolve the design-related problem.

The data excerpt in Table 5 above is an example of the 412 discussion episodes included in the data for this study. Although the topic itself is quite minor, several toilet seats, the excerpt illustrates just how many different perspectives were involved in the discussion. To ensure the quality of the design, all of these perspectives needed to be taken into account in the decision making. The excerpt also shows how managers cross the boundaries of the traditional division of expertise by actively contributing to the design work of a building.

\subsection{How did the projects differ and what was the effect of LPS used in the design phase?}

Figures 5 and 6 present how the number of discussions changed from one meeting to another. As shown in Figure 5, the discussions were most frequent at the beginning of Project 1. At that time, some of the necessary initial data for the design work was unavailable, and hence the work was falling behind schedule. Project 2 started more easily and had less discussion to begin with, but the discussion rate rose again in meeting 3 (Figure 5) due to the delays in the demolition work.

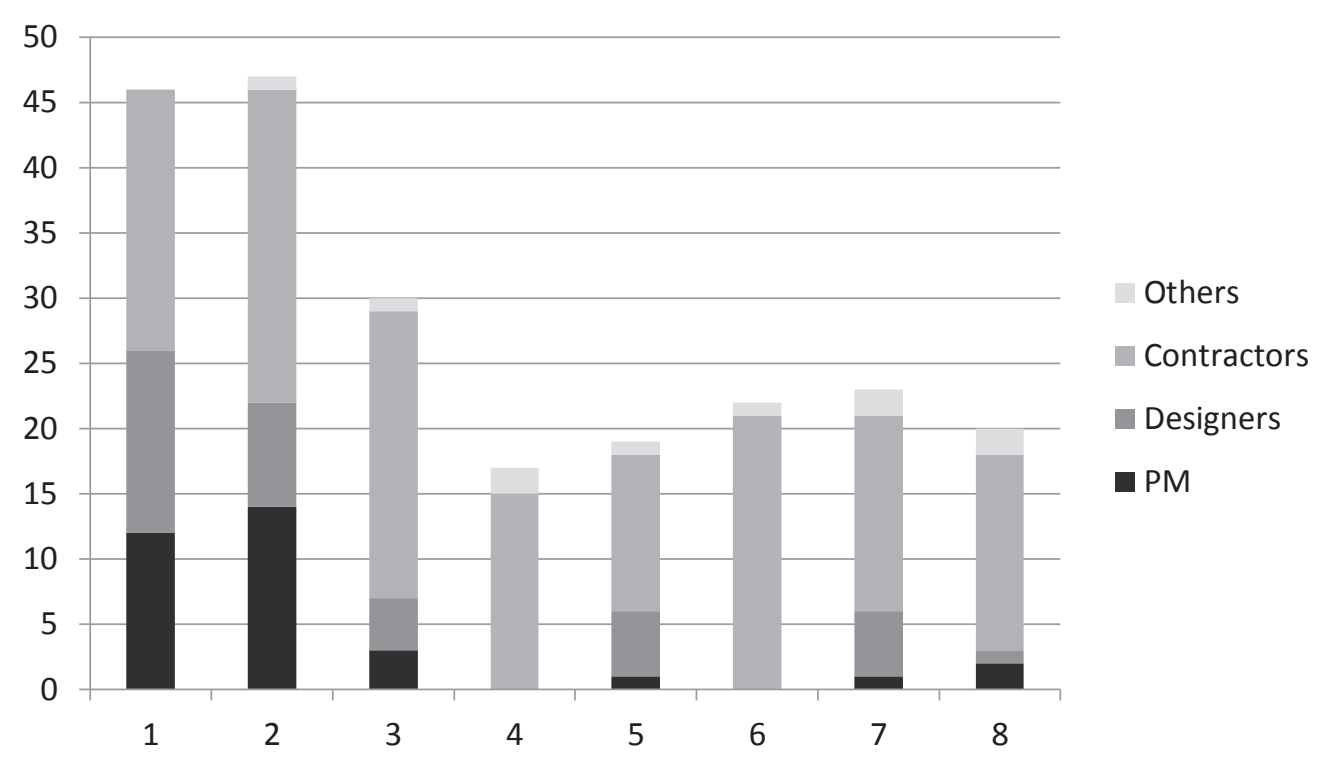

Figure 5. Number of discussions in Project 1 


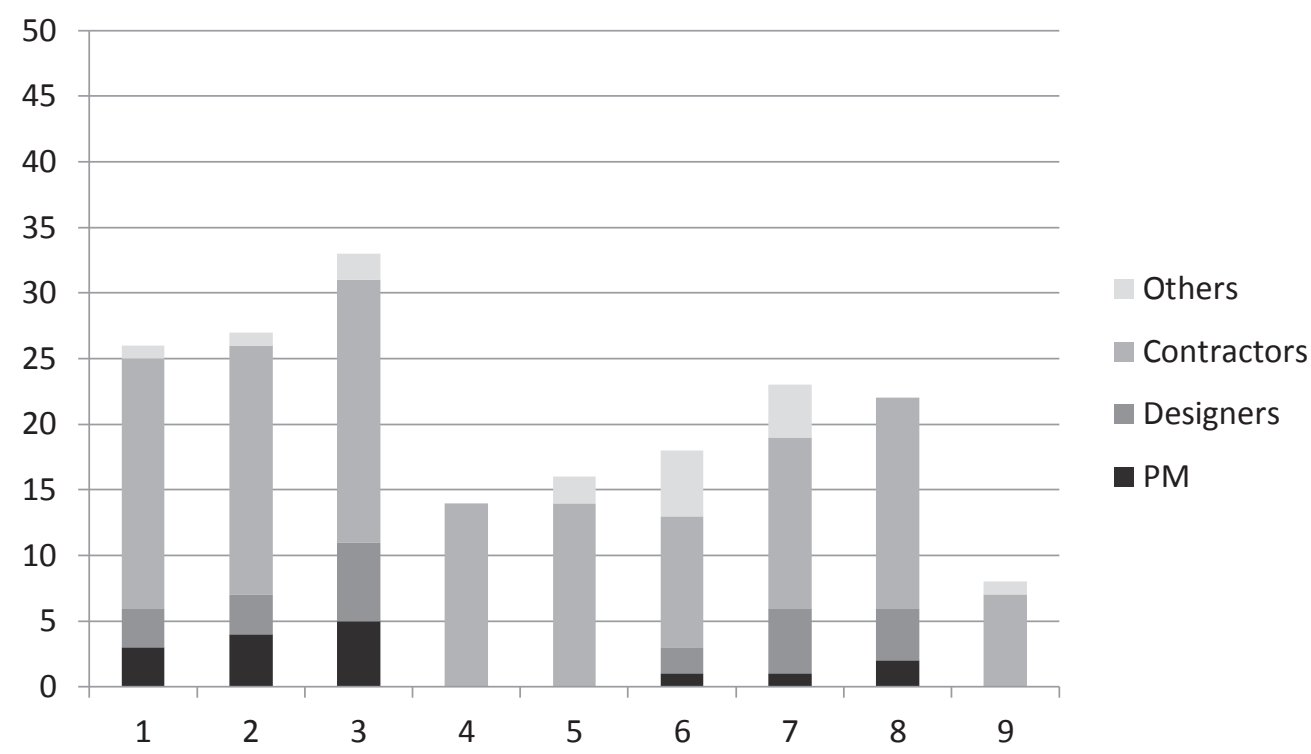

Figure 6. Number of discussions in Project 2

Based on this data, it seems that utilizing LPS in the design phase enabled the design team to adhere to the design schedule. Some of the work was even completed ahead of schedule. Although this improvement is obvious in Project 2, it is not justified to argue that LPS was the only reason for the enhanced performance. As the same design team members took part in both projects, they naturally learned to collaborate and develop common practices from one project to another.

As Table 4 shows, the most frequently discussed topics were the same in both projects. The same building parts seemed to cause problems and to require more discussions in both projects. Hence, implementing LPS in design management seemed to reduce the open questions in general (225 discussions vs. 187 discussions), but the critical topics remained the same.

Table 3 depicts a clear change between the projects. At the beginning of Project 1, 18 discussions were initiated by designers to clarify the initial data for the design work. None of these reasons were presented in Project 2 as these issues had already been resolved during the design phase, which enabled the designers to complete their design work on schedule. This reduced the discussion related to the initial data, non-existent design documents or missing design details in documents in Project 2.

However, in Project 2 the contractors required more modifications to and specifications for the existing design solutions. Common procedures were also more frequently discussed in this project.

The participation rates of different partners were quite similar in both projects. Changes included the more active role of the group labelled 'Other', mainly the maintenance manager, in Project 2. The decision- making based on this group's expertise nearly doubled in this project. This can be explained by the fact that during Project 2, the maintenance managers already had experience of the maintenance issues that occurred in Project 1, so they were more aware when it came to commenting on designs in the making. 


\section{Discussion}

The findings of this study showed that several open design-related issues still needed discussing and resolving during the construction phase. Resolving these issues to achieve the best outcome for the project called for expertise and knowledge input from different project partners. As the construction phase was ongoing, the contractors were the most active group in raising these issues. The findings support those of Alarcon et al. (1998) regarding design quality, incomplete drawings and the requirement for specifications. The design quality did not seem to meet the requirements of the construction and maintenance work at the beginning of the construction phase, even when BIM and clash detection processes were in use and the designers had long experience (a life-cycle project of four years) of working together.

The findings discredit the suggestion by Gorse et al. (2007), who claimed that project specificity makes it impossible to study what is discussed in meetings. On the contrary, the design-related topics that came under discussion in the construction phase seemed to remain the same from one project to another. These topics could be taken up as a developmental effort for project collaboration in the future in order to avoid incurring extra work and costs.

Discussions during site meetings are not just talk for the sake of talking, or solely related to design work but, rather, they are closely connected to construction and maintenance practices (Gherardi 2012; Nicolini 2012; Engeström 1999; Gluch and Räisänen 2009; Gluch et al. 2013). Opening a discussion can be seen as an effort to develop the project and to seek better solutions. Poirier and colleagues (2016) have explored collaborative expertise in construction and the implications that the transition to innovative project delivery approaches will have for this expertise. To support the project, one needs to collaborate, namely share one's knowledge or, in this case, one's concern for the design solution in order to get the best out of the project. (Poirier et al 2016) This is what is happening at the grass-roots level in the site meetings when the project partners initiate discussions on these open issues.

Dossick and Neff (2011) argue that BIM is potentially an efficient tool with which project partners can exchange explicit knowledge. In addition, 'messy talk' and informal, active and flexible conversations are needed to exchange tacit knowledge (Dossick \& Neff 2011) The findings of this study confirm these arguments. BIM was actively used in all design disciplines in these projects and the designers and design management certainly did their best to provide models for the construction managers. Nonetheless, joint discussion, modification and specification of the designs was needed before the contractors could execute their work based on the designs. On the other hand, emerging practices such as BIM, LPS or integrated project models can develop design and construction practices in a more collaborative direction and improve performance in terms of project organization (Eastman et al. 2011; Fischer et al. 2017; Al Hattab et al. 2015).

Based on this study, using LPS during the design phase helped the designers to complete their work in time, and to reduce the number of design-related open questions in the construction phase. However, it cannot be argued that LPS was the only reason 
behind the performance improvement in Project 2, as the development could also be attributed to learning from each other and from one project to another. Due to the limitations of this study, the effects of learning, other than the adoption of LPS, are difficult to rule out in the data.

\section{Conclusions}

The findings of this study reveal the topics and the number of design-related open questions that arose during the site meetings. In the worst cases, the number of designrelated discussion topics approached fifty in a meeting. The most discussed topics seemed to be the same in both projects. Construction managers were active both in bringing up issues as well as suggesting solutions to them. They actively shared their knowledge to develop design solutions to benefit the projects and to safeguard their own interests.

The findings emphasize the need for new collaborative design management methods and common practices for sharing each partner's expertise in the projects. This is needed to support deeper multi-professional collaboration for better design quality and construction work in projects. BIM, Lean Construction practices or integrated project models can readily play a part in the development of these project practices. Further research is needed on how this collaboration should be organized so as to yield the best results for the project as a whole.

\section{References}

Al Hattab, M., and Hamzeh, F. R. 2015. Using Social Network Theory and Simulation to Compare Traditional versus BIM-lean practice for design error management. Automation in Construction, Elsevier, pp. 59-69, doi 10.1016/j.autcon.2015.02.014.

Alarcon, L. F. \& Mardones, D. A. 1998. Improving the Design-Construction Interface. Proceedings IGLC '98. $6^{\text {th }}$ Annual Conference of the International Group of Lean Construction. Guaruja, Brazil.

Ballard, H. G. 2000. The Last Planner System of Production Control. Doctoral Dissertation, Faculty of Engineering, University of Birmingham.

Bertelsen, S. \& Koskela, L. 2005. Approaches to managing complexity in construction project production. International Conference on Complexity and the Built Environment, Liverpool, UK, 1-13.

Bresnen, M. 2009. Living the dream? Understanding partnering as emergent practice. Construction Management and Economics, Vol 27(4):1144-59.

Boellstorff, T. Nardi, B. Pearce, C. \& Taylor, T. L. 2012. Ethnography and virtual worlds. A handbook of method. Princeton and Oxford: Princeton University Press.

Boudeau, C. 2013. Design team meetings and the coordination of expertise: the roof garden of a hospital. Journal of Construction Management and Economics, Vol 31: 7889. 
Bucciarelli, L. L. 1988. An ethnographic perspective on design engineering. Design Studies, Vol 9(3): 159-168.

Ding, Z., Ng, F. \& Cai, Q. 2007. Personal constructs affecting interpersonal trust and willingness to share knowledge between architects in project design teams. Journal of Construction Management and Economics, Vol 25: 937-950.

Dossick, C. C. \& Neff, G. 2011. Messy talk and clean technology: communication, problem-solving and collaboration using Building Information Modelling. Journal of Engineering Project Organization, Vol 1(2), 83-93.

Eastman, C. Teicholz, P. Sacks, R. \& Liston, K. 2011. BIM Handbook. A Guide to Building Information Modeling for Owners, Managers, Designers, Engineers, and Contractors. New Jersey: John Wiley and Sons, Inc.

Engeström, Y. 2015/1987. Learning by expanding. An activity-theoretical approach to developmental research. $2^{\text {nd }}$ ed. Cambridge: Cambridge University Press.

Engeström, Y. 2008. From teams to knots. Activity-theoretical studies of collaboration and learning at work. Cambridge: Cambridge University Press.

Engeström, Y. 2001. Expansive learning at work: toward an activity theoretical reconceptualization. Journal of Education and Work, Vol. 12(1):133-156.

Engeström, Y. 1999. Communication, Discourse and Activity. The Communication Review, Vol 3, 165-185.

Engeström, Y. 1995. Object, contradictions and collaboration in medical cognition: An activity-theoretical perspective. Artificial Intelligence in Medicine, 7: 395-412.

Engeström, Y. \& Sannino, A. 2010. Studies of expansive learning: Foundations, findings and future challenges. Educational Research Review, Vol 5: 1-24.

Fetterman, D. M. 2010. Ethnography step-by-step. $3^{\text {rd }}$ ed. Thousand Oaks, CA, New Delhi, India, London, UK, Singapore: Sage Publications.

Fischer, M., Ashcraft, H., Reed, D. \& Khanzode, A. 2017. Integrating project delivery. Hoboken, New Jersey: John Wiley \& Sons, Inc.

Foley, J. \& MacMillan, S. 2005. Patterns of interaction in construction team meetings. International Journal of CoCreation in Design and the Arts, Vol 1: 19-37.

Gerth, R., Boqvist, A., Bjelkemyr, M. \& Lindberg, B. 2013. Design for Construction: utilizing production experiences in development. Journal of Construction Management and Economics, Vol 31: 135-150.

Gherardi, S. 2012. How to conduct a practice-based study. Problems and methods. Cheltenham, UK and Northampton, Mass, USA: Edward Elgar.

Gluch, P., Johansson, K. \& Räisänen, C. 2013. Knowledge sharing and learning across community boundaries in an arena for energy efficient buildings. Journal of Cleaner Production, Vol 48: 232-240.

Gluch, P. \& Räisänen, C. 2009. Interactional perspective on environmental communication in construction projects. Building Research \& Information, Vol 37 (2): 
164-275.

Gorse, C. A. \& Emmitt, S. 2007. Communication behavior during management and design team meetings: a comparison of group interaction. Journal of Construction Management and Economics, Vol 25: 1197-1213.

Gorse, C. A. \& Emmitt, S. 2009. Informal interaction in construction progress meetings. Journal of Construction Management and Economics, Vol 27: 983-993.

Hamzeh, F. R., Ballard, G. \& Tommelein, I. D. 2009. Is the Last Planner System Applicable to Design? A Case Study. In Proceedings of the 17th Annual Conference of the International Group for Lean Construction (IGLC 17). Taipei, Taiwan, 15-17 July 2009, 399-410.

Hardin, B. 2009. BIM and construction management. Proven tools, methods, and workflows. Indianapolis, Indiana, US: Wiley Publishing, Inc.

Henderson, C. 1999. On line and on paper: visual representations, visual culture, and computer graphics in design engineering. Cambridge, MA: The MIT Press.

Josephson, P-E. \& Hammarlund, Y. 1996. Costs of quality defects in the 1990s. Report 49, Building Economics and Construction Management, Chalmers University of Technology, p. 125 (in Swedish).

Josephson, P-E. 1998. Causes of Defects in Construction - a study of seven building projects in Sweden. Working Paper, Department of Management of Construction and Facilities, Chalmers University of Technology.

Kerosuo, H., Miettinen, R., Paavola, S., Mäki, T. \& Korpela, J. 2015. Challenges of the expansive use of Building Information Modeling (BIM) in construction projects. Production (Produçao), Vol 25(2): 289-297.

Kerosuo, H., Mäki, T., Codinhoto, R., Koskela, L. \& Miettinen, R. 2012. In time at last Adaption of Last Planner tools for the design phase of a building project. In I. D. Tommelein \& C. L. Pasquire 20th Annual Conference of the International Group for Lean Construction. San Diego, USA, 18-20 July 2012.

Koskela, L., Ballard, G. \& Tanhuanpää, V-P. 1997. Toward lean design management. Proceedings of the 5th Annual Conference for International Group for Lean Construction, Gold Coast, Australia.

Lahdenperä, P. 2012. Making sense of the multi-party contractual arrangements of project partnering, project alliancing and integrated project delivery. Construction Management and Economics, Vol 30 (1): 57-79.

Li, H. Lu, W. \& Huang, T. 2009. Rethinking project management and exploring virtual design and construction as a potential solution. Construction Management and Economics, Vol 27: 363-371.

Lyon, D. 2013. The Labour of refurbishment. In S. Pink, D. Tutt \& A. Dainty (eds.), Ethnographic Research in the Construction Industry, 23-39. Abingdon: Taylor \& Francis. 
Miettinen, R. Kerosuo, T. Mäki, T. \& Paavola, S. 2012. An activity theoretical approach to BIM. In G. Gudnasen and R. Scherer (eds.), eWork and eBusiness in architecture, engineering and construction. Proceedings of the European Conference on Product and Process Modeling, 777-781. London: Taylor \& Francis.

Miettinen, R. \& Paavola, S. 2014. Beyond the BIM utopia: Approaches to the development and implementation of building information modeling. Automation in Construction, Vol 43, 84-91.

Mäki, T. \& Kerosuo, H. 2015. Site managers' daily work and the uses of building information modelling in construction site management. Construction Management and Economics, Vol 33: 163-175.

Mäki, T. 2015. Multi-disciplinary discourse on design-related issues in construction site meetings. 8th Nordic Conference on Construction Economics and Organization. Procedia Economics and Finance, Vol 21: 231-238.

Nicolini, D. 2012. Practice theory, work \& organization. Oxford: Oxford University Press.

Poirier, E., Forgues, D. \& Staub-French, S. 2016. Collaboration through innovation: implications for expertise in the AEC sector. Journal of Construction Management and Economics, Vol 34: 769-789.

Pryke, S. D. 2004. Analysing construction project coalitions: exploring the application of social network analysis. Journal of Construction Management and Economics, Vol 22: 787-797.

Sacks, R., Whyte, J., Swissa, D., Raviv, G., Zhou W. \& Shapira, A. 2015. Safety by design: dialogues between designer and builders using virtual reality. Construction Management and Economics, Vol 33: 55-72.

Trigunarsyah, B. 2007. Project designers' role in improving constructability of Indonesian construction projects. Journal of Construction Management and Economics, Vol 25: 207-215.

\section{List of figure captions}

Figure 1. Partially shared object of two activity systems of design and construction (adapted from Engeström 2001, 136)

Figure 2. Intertwined activity systems of design and construction management (modified from Engeström \& Sannino 2010, 6)

Figure 3. Design-related issues and open questions raised in the site meetings.

Figure 4. Participation in the design-related discussions in the site meetings and identification of whose expertise created the design solutions.

Figure 5. Number of discussions in Project 1

Figure 6. Number of discussions in Project 2 